\title{
Bitumen aging on the surface of crushed limestone at high temperatures
}

\author{
Muhammet Salihov ${ }^{1}$, Evgeniy Veyukov ${ }^{1 *}$, Ekaterina Lomakina $^{1}$, and Lidia Malyanova ${ }^{2,3}$ \\ ${ }^{1}$ Volga State University of Technology, Lenin Sq., 3, Yoshkar-Ola, Russia, 424000 \\ ${ }^{2}$ Chuvash State University named after I.N. Ulyanov, Moskovsky pr-t, 15, Cheboksary, Russia, \\ 428017 \\ ${ }^{3}$ Cheboksary Institute Of Moscow Polytechnic University, K. Marx Street 54, Cheboksary, Russia, \\ 428000
}

\begin{abstract}
In road structural layers, mixtures of crushed limestone with oil bitumen are used as a structural material (black crushed stone), or as a part of asphalt concrete organic-mineral mixtures. Since limestone deposits are located in a great number of regions, their increased use makes it possible to reduce transportation costs in the estimated road construction cost. In the meantime, it is necessary to conduct a study of the aging of bitumenmineral mixtures during their preparation and use in road structures when using local limestone materials. This article presents the results of the studies, during which the effect of bitumen aging on some properties of bitumen-mineral mixtures was studied using a new method. The developed method for studying bitumen aging compares favorably with the already known methods and is protected by the Patent of the Russian Federation No. 2654954. Due to this method, it becomes possible to study the effect of aging on the values of any indicator according to a single model - both complex (e.g. asphalt concrete) and simple systems (crushed stonebitumen, sand-bitumen, etc.). This approach provides a more accurate prediction of the material behavior both during preparation and service in road structures. The execution of work involves the preliminary establishment of the optimal bitumen and crushed stone ratio, at which the highest average density and ultimate compressive strength at $+20{ }^{\circ} \mathrm{C}$ is provided. Laboratory testing of samples indicated the dynamic pattern of the value of the aging coefficient and the aging rate in terms of the ultimate compressive strength at $+50{ }^{\circ} \mathrm{C}$ and the elastic modulus.
\end{abstract}

\section{Introduction}

Crushed limestone is widely used in the composition of bitumen-mineral materials asphalt concrete, stone mastic asphalt, black crushed stone etc. The use of crushed limestone in road construction is efficient and expediential by the virtue of the fact that their deposits are located in the Russian Federation more evenly than igneous rocks and therefore, its use requires relatively lower transportation costs. For instance, the installed annual capacity of stone-crushing plants in the Volga-Vyatka region (Mari El Republic,

\footnotetext{
* Corresponding author: VeukovEV@volgatech.net
} 
Chuvash Republic, Udmurt Republic and Kirov Oblast) amounts to 2307 thousand $\mathrm{m}^{3}$ [1]. The average strength of the primary rocks in them is 30-40 MPa. In compliance with GOST 9128-2013 [2], crushed stone made of such rocks can be used as a coarse aggregate in type $\mathrm{B}$ asphalt concrete and black crushed stone, or for mineral powder production. In the meantime, GOST R58406.2-2020 [3] states that such crushed stone can be used with/without processing with binders only in the bases of the roads of regional significance, to strengthen roadsides, etc. Therefore, it is relevant to study the use of crushed limestone processed with organic binders (bitumen) in road structures during operation.

\section{Problem statement and study objective}

It is a well-known fact that bitumen films are formed on outer surfaces of crushed limestone when combined with bitumen. The thickness of bitumen films and their structure depends on the type of rock and bitumen, grain size, surface purity, temperature at the time of their combination, etc. It is also known that on the surface of porous carbonate rocks, mainly consisting of calcites and magnesites, bitumen films consist of three zones - high bond strength, poor bond strength and free, i.e. bitumen delamination occurs. In these conditions, light fractions of bitumen penetrate deep into crushed stone grains due to the pores on their surface. This leads to an increased bond strength between the surface of a solid and a liquid due to the ongoing physical and chemical processes, and, at high temperatures, to the formation of chemical bonds. Because of this, the stability of the bitumen films increases in aggressive media. Under the influence of polar liquids (including oil bitumen) on the surface of a solid, it decreases in strength, according to the Rebinder effect. And due to the effect of the adsorptive increase in strength, opposite processes occur [1]. All abovementioned affects the properties of oil films, in particular, their adhesive ability. During the mixtures preparation and their use in engineering structures, structural changes continue, since over time the fragility of bitumen films increases, which leads to a decrease in strength of the road structural layers [4-10]. These phenomena are commonly referred to as aging.

In consideration of the foregoing, it can be stated that understanding the issues and development of the ability to manage aging processes is one of the most acute problems in ensuring the performance of bitumen-mineral materials in road structures, in particular, mixtures of crushed limestone with oil bitumen.

\section{Research approach, experimental work and its essence}

The accuracy of the research results obtained for the aging process of bitumen-mineral materials largely depends on the chosen research methods. To date, there is a standard method for studying bitumen aging, the point of which is to measure the weight loss of bitumen during heating at $+163{ }^{\circ} \mathrm{C}$ for 5 hours according to GOST 33140-2014 [11] with free air supply. However, this method does not take into account the effect of base material on the condition of the films. In 2018, a new method for studying the aging processes of bitumen films on the surfaces of individual mineral grains of bitumen-mineral mixtures was developed at the Department of Building Technologies and Highways (Volga State University of Technology) [12]. This method has the following significant advantages:

1) allows to study the aging process of bitumen films on the surfaces of any mineral components of bitumen-mineral mixtures and assess their role separately in the aging process; 
2) allows to study the dynamic pattern of properties during aging, i.e. at any stages of structure formation, starting from the combining the components in a loose state until the complete loss of mechanical strength in a compacted state;

3 ) the study of the aging of bitumen-mineral mixtures is carried out under laboratory conditions, which makes it possible to adjust the mixture composition during the technical project development at the design stage;

4) allows to study the bitumen films aging by choosing, as the main, one of the most sensitive to temperature changes indicators according to GOST 9128-2013 or GOST R58406.2-2020.

For the experiment, samples of the crushed limestone and oil bitumen, dried to constant weight and heated to operating temperatures, are taken and mixed in optimal proportion until a homogeneous mixture is obtained. The optimal proportion is established as follows: prepare samples of crushed stone mixtures, in this case, samples with a fraction of 5-20 mm with a strength grade of 400 from Novotoryalskiy stone crushing plant located in the Mari El Republic, and road oil bitumen grade BND 70/100 from the Kstovsky oil refinery located in the Nizhny Novgorod region. The Bitumen:Crushed stone ratio $=1: 8 ; 1: 9 ; 1: 15$; 1:20; and 1:22. Standard cylindrical specimens were made from these mixtures at a working temperature $\left(+140 \ldots+160^{\circ} \mathrm{C}\right)$. These specimens have a diameter size of $71.4 \mathrm{~mm}$, according to GOST 12801-98 [13]. In 24 hours, they were tested in order to establish the values of the ultimate compressive strength at $+50{ }^{\circ} \mathrm{C}$. The test results are presented in Table 1.

Table 1. Test results to establish the optimal ratio of bitumen to crushed stone

\begin{tabular}{|c|c|c|c|}
\hline No. & $\begin{array}{c}\text { The ratio of bitumen to } \\
\text { crushed limestone }\end{array}$ & Average density, $\mathbf{g} / \mathbf{c m}^{\mathbf{3}}$ & $\begin{array}{c}\text { Compressive strength } \\
\mathbf{a t}+\mathbf{2 0}{ }^{\circ} \mathbf{C}, \mathbf{M P a}\end{array}$ \\
\hline 1 & $1: 8$ & 2.02 & 0.20 \\
\hline 2 & $1: 9$ & 2.17 & 0.36 \\
\hline 3 & $1: 15$ & 2.14 & 0.27 \\
\hline 4 & $1: 20$ & 2.10 & 0.23 \\
\hline 5 & $1: 22$ & 2.11 & 0.24 \\
\hline
\end{tabular}

The analysis of the data obtained shows that the highest average density and compressive strength are provided when the ratio of bitumen to crushed stone is 1:9. This ratio is taken as optimal.

The next step is to prepare samples of bitumen-limestone crushed stone in a ratio of 1:9, place them in even layers on metal trays to a ventilated thermal furnace, where the set temperature $\left(+150^{\circ} \mathrm{C}\right)$ is automatically maintained.

After the estimated heating time $(0,1,3,5,7$, etc. hours $)$, samples are removed from the furnace and standard cylindrical samples are formed and tested according to GOST 1280198 to determine the average density, compressive strength at $+50{ }^{\circ} \mathrm{C}$ and - according to the VSN 46-72 [14] - elastic modulus - $E_{\text {elastic }}$. Further, the aging coefficient $R_{C}^{+50^{\circ} \mathrm{C}}$

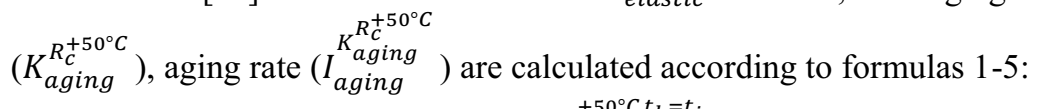

$$
K_{\text {aging }}^{R_{C}^{+50^{\circ} \mathrm{C}}}=\frac{K_{\text {aging }}^{R_{c}^{+50^{\circ} \mathrm{C}, t_{h}=t_{i}}}}{K_{\text {aging }}^{R_{c}^{+50^{\circ} \mathrm{C}, t_{h}=0}},}
$$

where $I n d_{\mathrm{i}}^{\mathrm{T}, \mathrm{t}_{h}=\mathrm{t}_{\mathrm{i}}}$ и $I n d_{\mathrm{i}}^{\mathrm{T}, \mathrm{t}_{\mathrm{h}}=0}$ - the values of the indicators of the studied physical and mechanical properties of the bitumen-mineral mixture before and after heating at a high temperature for a time from 0 to $t_{i}$, respectively; $t_{h}$ - heating time of mixtures; 


$$
I_{\text {aging }}^{K_{\text {aging }}^{R_{C} 50^{\circ} \mathrm{C}}}=\frac{\Delta K_{\text {aging }}^{R_{C}^{+50^{\circ} \mathrm{C}}}}{\Delta t_{h}},
$$

where $\Delta K_{\text {aging }}^{R_{C}^{+50^{\circ} \mathrm{C}}}$ - change in the aging coefficient values during $\Delta t_{h}$;

$$
\begin{gathered}
E_{\text {elastic }}^{+20^{\circ} \mathrm{C}}=\frac{P \cdot D_{\text {sample }}}{l_{\text {elastic }}} \cdot\left(1-\mu^{2}\right), \\
P=\frac{P_{f_{i-1}}}{S_{\text {sample }}},
\end{gathered}
$$

where $P_{f_{i-1}}-$ load on a sample before its failure; $S_{\text {sample }}$ - sample area, $40 \mathrm{~cm}^{2} ; \mu-$ Poisson's ratio; $l_{\text {elastic }}$ - elastic deformation of the sample:

$$
l_{\text {elastic }}=l_{\text {comp }}-l_{\text {perm }} \text {, }
$$

where $l_{\text {comp }}$ - complete deformation at the moment of the load, $P_{f_{i-1}} ; l_{\text {perm }}-$ permanent deformation after removal of the load.

\begin{tabular}{|c|c|c|c|c|}
\hline Heating time $t_{h}$, hour & $\begin{array}{c}\text { Average } \\
\text { density } \boldsymbol{\delta}_{\boldsymbol{a v}}, \\
\mathbf{g}^{\mathbf{g} \mathbf{c m}^{3}}\end{array}$ & $\begin{array}{c}\text { Compressive } \\
\text { strength at } \\
+50^{\circ} \mathrm{C} \\
R_{C}^{+50^{\circ} \mathrm{C}}, \mathrm{MPa}\end{array}$ & $\begin{array}{c}\text { Aging } \\
\text { coefficient } \\
K_{\text {aging }}^{R_{c}^{+50^{\circ} \mathrm{C}}}\end{array}$ & $\begin{array}{c}\text { Aging rate } \\
\boldsymbol{K}_{\text {aging }}^{R_{\text {aging }}^{+50^{\circ} \mathrm{C}}} \\
\text {, hour }^{-1}\end{array}$ \\
\hline 0 & 2.02 & 0.31 & 1.00 & \\
\hline 1 & 2.11 & 0.39 & 1.26 & +0.26 \\
\hline 3 & 2.08 & 0.53 & 1.71 & +0.23 \\
\hline 5 & 2.08 & 0.38 & 1.23 & -0.22 \\
\hline 7 & 2.10 & 0.32 & 1.03 & -0.10 \\
\hline
\end{tabular}

The experiment results are shown in Tables 2 and 3.

Table 2. Results of experiments on the study of samples aging made of a mixture of bitumen and

\begin{tabular}{|c|c|c|c|c|}
\hline \multirow[b]{2}{*}{$\begin{array}{l}\text { Heating time of the } \\
\text { mixture } t_{h} \text {, hour }\end{array}$} & \multicolumn{3}{|c|}{ Sample deformation, mm } & \multirow{2}{*}{$\begin{array}{c}\text { Elastic } \\
\text { modulus } \\
E_{\text {elastic }}^{+20^{\circ} \mathrm{C}} \\
\mathrm{MPa} \\
\end{array}$} \\
\hline & $l_{\text {comp }}$ & $l_{\text {perm }}$ & $l_{\text {elastic }}$ & \\
\hline 0 & 53,78 & 52,12 & 1,66 & 205,9 \\
\hline 1 & 48.53 & 47.78 & 0.78 & 403.3 \\
\hline 3 & 48.54 & 48.09 & 0.45 & 581.1 \\
\hline 5 & 49.13 & 50.04 & -0.91 & 0 \\
\hline 7 & 48.14 & 48.88 & 0.74 & 0 \\
\hline
\end{tabular}
crushed stone in a $1: 9$ ratio at $+150{ }^{\circ} \mathrm{C}$

Table 3. Results of experiments to establish the values of the elastic modulus of samples

The analysis of the data indicated in Table 2 shows that during the aging process of the bitumen-crushed stone mixture:

1) the average density increases slightly;

2) the compressive strength values at $+50{ }^{\circ} \mathrm{C}$ in the initial heating period (up to 3 hours) increase, then decrease but are not lower than initial values.

The analysis of the data obtained (Table 3 ) shows that the elastic modulus values in the initial aging period (up to 5 hours) intensively increase, then rapidly decrease to zero upon further heating.

The results of experimental studies on the aging of bitumen-crushed stone mixtures show that there is no contradiction between them and the conclusions of well-known scientists on the study of bitumen-mineral mixtures [4, 7, 15-19]. 
The obtained measurement results were further processed in the CurveExpert 4 software environment [20]. The following mathematical dependence is obtained with a sufficient degree of convergence:

$$
\begin{gathered}
K_{\text {aging }}^{R_{C}^{+50^{\circ} \mathrm{C}}=1.3406}+0.3708 \cdot \cos \left(0.9182 \cdot t_{h}-2.7138\right) \\
S=0.00432 ; r=0.99997 .
\end{gathered}
$$

As has been mentioned above, the bitumen film is divided into 3 layers when crushed limestone is combined with bitumen: a solid layer that cannot glue adjacent mineral particles (it is located closer to the surfaces), a semi-bound and unbound layers.

Under the action of high temperature, several simultaneous processes occur: a chemical reaction between crushed stone and bitumen, the transition of the layer into asphaltenes are intensified and light fractions volatilize. This leads to the embrittlement of bitumen films and the loss of their adhesive ability. Subsequently, the resistance to external loads and the elastic properties of bitumen-mineral materials decrease under the influence of external forces.

\section{Conclusions}

1. The experiment results show that the highest density of samples made of a mixture of crushed limestone with viscous bitumen is achieved when compacted by pressing in a ratio of 1:9.

2. It is found that when the mixture is heated at a high temperature $\left(+150{ }^{\circ} \mathrm{C}\right)$ for 5 hours, the aging process accelerates and a significant increase in the compressive strength values is observed at $+50{ }^{\circ} \mathrm{C}$ (by $59.5 \%$ of the initial strength). At further heating, the opposite process occurs. After 7 hours, the value of the compressive strength of the samples at $+50{ }^{\circ} \mathrm{C}$ drops approximately to the initial values. It is related to the embrittlement of bitumen films in the samples. It is necessary to develop methods for regulating aging processes to prevent their limiting value.

3. With mixtures aging at high temperatures, the value of the elastic modulus increases in the initial period, and then sharply decreases, as well as the compressive strength.

\section{References}

1. M.G. S 1999 Development of scientific and practical bases of volumetric impregnation of low-strength stone materials with liquid binders for road construction: dis ... doct. tech. nak (Moscow: MADI)

2. GOST 9128-2013. Asphalt concrete mixture, polymerisation, asphalt concrete, polymerisation for roads and airfields. Technical conditions (Moscow: Standartinform)

3. GOST R 58406.2-20. Automobile roads of General use. Hot asphalt concrete and asphalt concrete mixes. Technical conditions (Moscow: Standartinform)

4. Wasilewska M, Małaszkiewicz D and Ignatiuk N 2017 Evaluation of Different Mineral Filler Aggregates for Asphalt Mixtures IOP Conference Series: Materials Science and Engineering

5. Teltayev B and Radovskiy B 2018 Predicting thermal cracking of asphalt pavements from bitumen and mix properties Road Mater. Pavement Des.

6. Porto M, Caputo P, Loise V, Teltayev B B, Angelico R, Calandra P and Rossi R C 2019 New experimental approaches to analyse the supramolecular structure of rejuvenated aged bitumens News Natl. Acad. Sci. Repub. Kazakhstan, Ser. Geol. Tech. Sci.

7. I.V. K 1986 Ways to save bitumen in road construction (Moscow: Transport) 
8. I.M. R 1984 Organic binders for road construction (Moscow: Transport)

9. L. B. Gezentsvey, N. In. Gorelyshev, A. M. Boguslavsky I V K 1985 Road asphalt (Moscow: Transport)

10. I.V. K 1981 Model of the structure of bituminous film on mineral grains in asphalt concrete Izv. VUZov. Ser. "Construction Archit. 8 63-7

11. GOST 33140-2014. Automobile roads of General use. Oil road bitumen is viscous. Method for determining the resistance of bitumen to aging under the influence of high temperature and air (RTFOT method) (Moscow: Standartinform)

12. Salikhov M.G., Veyukov E.V., Sabirov L.R. M L A method for determining the speed and intensity of aging of asphalt concrete. Patent for invention No. 2654954 dated 13.02.2017

13. GOST 12801-98. Materials based on organic binders for road and airfield construction. Test methods (Moscow: GUP TSPP)

14. VSN 46-72. Instructions for the design of road clothing of non-rigid type (Moscow: Transport)

15. S.S. S 2008 Methods of minimizing the aging of bitumen in the working boiler in the preparation of hot asphalt-concrete mixtures: Abstract of the thesis of the Candidate of technical Sciences (Rostov-on-Don: WGEC)

16. Skripkin A.D., Starkov G. B. K D A 2010 Aging of bitumen in the technological process of its preparation for the production of asphalt concrete mixtures Collect. Artic. reports Annu. Sci. Sess. Assoc. Asph. Concr. Res. 46-53

17. V. G D 2010 Technological and operational aging of tar-concrete mixtures and tarconcrete mixtures and methods of deceleration: Abstract of the Cand. of technical sciences (Don: NASA)

18. Tan T N 2010 Regulation of thermal-oxidative stability of road bitumen and bituminous materials: dis. ... cand. tech.nauk. (Moscow)

19. Liao K, Zhao Z, Xuan M, Liu Z, Cong Y and Wei Y 2003 A Study on Aging Kinetics of Asphalt Based on Softening Point Pet. Sci. Technol. 21 1575-82

20. M. M P 2006 Mathematical modeling. Identification of one-factor statistical regularities: Textbook (Yoshkar-Ola: VSUT) 